\title{
Critical Response
}

\section{Sunday Adeniyi Fasoro* \\ Immigration, Humanity, and Morality}

https://doi.org/10.1515/openps-2019-0004

received March 4, 2019; accepted May 13, 2019.

\begin{abstract}
The trend toward the concept of humanity in political theory has arisen largely as a reaction against the mistreatment of vulnerable people such as immigrants. The issue of immigrants' vulnerability has led political thinkers to ponder on how to apply the principle of humanity to the question of the treatment of immigrants. I would like to address this matter by examining two questions: what is humanity, is it a value property, or a virtue? Does it really matter if the means by which an immigrant immigrates is demeaning to his own humanity as a person? The most common or intuitive reply to these questions would probably be: 'humanity' is simply a value-bestowing property, so regardless of immigrants' actions they are owed respectful treatment. The aim of this paper is to emphasise instead that 'humanity' should be conceived as a virtue of actual commitment to act on moral principles. I explore three different meanings of humanity. First, I discuss 'humanity' as the common ownership of the earth. Second, I discuss 'humanity' as a value property. Third, I discuss humanity as a virtue of acting, on the one hand, with humanity, and on the other hand, on moral principles.
\end{abstract}

Keywords: Immigrants’ Vulnerability; Humanity; Dignity; Good will; Respect; Morality.

\section{Immigrants' Vulnerability}

Immigrants' vulnerability has been described as the subjects of human rights - grounded in the principle of humanity. ${ }^{1}$ The urgency to promote and protect the humanity of immigrants is necessitated by the seriousness of this vulnerability. Immigrants are susceptible to all kinds of inhumane treatment such as human rights violations, abuse, and discrimination. Immigrants, women, and children are particularly susceptible to human trafficking and the terrible forms of abuse that it involves. As a result, the value of immigrants requires promotion and protection as an inviolable right. The ethical and political question about protection of "inviolable rights of all human beings" has become a legal text in many of international documents, including the United Nations Charter (UN), the Universal Declaration of Human Rights (UDHR), the International Organisation of Migration's Constitution (IOM), the International Bill of Human Rights, the International Covenant on Civil and Political Rights, and the Convention on the Rights of the Child (UNCRC).

Indeed, immigration statistics raise serious questions about the need to protect immigrants, at least for the sake of humanity. According to the U.N. report, between 1985 and 1990 the number of international immigrants increases just by $0.6 \%$ and subsequently decreases by $0.1 \%$ between 1990 and 2000. Since 2005, the number is growing faster than the world population. By 2017, the number of international immigrants has risen to 258 million which represent $3.4 \%$ of the world population, and an increase of $17 \%$ and 49\% from 2010 and 2000 respectively. ${ }^{2}$ This sharp increase

1 Bustamante, "Immigrants' Vulnerability as Subjects of Human Rights.”

2 Barbara Kobler, and Pablo Lattes. "International Migration Report 2017: Highlights (ST/ESA/SER.A/404).” United Nations, Department of Economic and Social Affairs, Population Division. 2017. Accessed December 21, 2018, 1. http://www.un.org/en/development/desa/population/migration/publications/migrationreport/docs/MigrationReport2017_Highlights.pdf.

*Corresponding author: Sunday Adeniyi Fasoro, TU Berlin, Berlin, Germany, E-mail: safasoro@gmail.com 
in numbers suggests that there is a large influx of immigrants crossing international borders, and it raises the question about how immigrants should be treated.

In light of this, Philip Cole describes the sense of what immigrants' vulnerability entails. According to him, "any group which shares characteristics with those identified as outsiders will themselves be in a vulnerable position. Their membership will be constantly questioned; they will be subjected to forms of surveillance from which other members are free, and their access to the public sphere of citizenship will become hazardous". ${ }^{3}$ In Cole's description, immigrants are vulnerable by virtue of their membership status in foreign countries. Insofar as they are not seen as an insider, they are automatically vulnerable to discriminations and abuses. Before Cole, Walzer had described immigrants and stateless persons as vulnerable and unprotected people because "they have no guaranteed place in the collectivity and are always liable to expulsion, and that is a condition of infinite danger". ${ }^{4}$ Both Walzer and Cole seem to attach immigrants' vulnerability problem with membership status in the public sphere.

Being regarded as an outsider is a great disadvantage to immigrants in a foreign country. Kukathas gave a description of the disadvantage by associating the degree of the danger it entails with uncertainty and deportation. He claims that "the threat of deportation makes immigrants vulnerable to unscrupulous employers or disgruntled neighbours". ${ }^{5}$ For this reason, immigration control requires behavioural control and cooperation of employers and neighbours, so that immigrants' vulnerability exposure can be minimised. Pécoud and de Guchteneire seem to agree with Kukathas but added that immigration control does not only increase the vulnerability of immigrants but also obscures immigration policies and increases security threats by enhancing business opportunities for smugglers and traffickers and by making flows invisible. ${ }^{6}$ This implies that there is a connection between immigration control and policies, human smuggling and trafficking, and immigrants' vulnerability. Pécoud and de Guchteneire argue that "tight immigration control and policies create situations of illegality and mistrust that make co-operative border management even more difficult". ${ }^{7}$ They argue that border controls do not actually stop smugglers and traffickers but rather provoke them to seek an alternative route.

As a way forward, David Held suggests that since the degrees of mutual interconnectedness and immigrants' vulnerability are rapidly growing, a moral framework must be created that focuses public policy on immigrants' vulnerability. ${ }^{8}$ But a moral framework cannot be created in a vacuum without focusing on a specific problem to be addressed. This is why Bauder, Sassen, Kukathas, Pécoud and de Guchteneire have identified immigration controls and the associated enforcement practices as the actual problem that renders immigrants vulnerable. ${ }^{9}$ This implies that it is not only being an outsider that subjects an immigrant to vulnerability, but also the actual enforcement practices associated with immigration control. So, on Held's account, public policy must be directed at immigrants' vulnerability through immigration policies and laws that address difficulties faced by immigrants at the border and within the community.

David Miller, on the other hand, appears to think that immigrants' vulnerability argument is cherry picking because human beings, in general, are needy and vulnerable creatures with basic rights that are worthy of protection and respect from everyone. Although, Miller thinks that "action is urgently needed to protect the rights of the group of people" such as immigrants and minority groups, he concurrently thinks that he is not certain on whom the responsibility falls. ${ }^{10}$ In order to determine how to assign this moral responsibility, Miller discusses the duty to respect the basic rights of "strangers or foreigners", as he describes them. In his final analysis, Miller affirms that our highest duties are negative ones rather than positive ones, that "it is important not to violate duties to oneself than to prevent others from violating theirs". ${ }^{11}$

3 Cole, Philosophies of Exclusion: Liberal Political Theory and Immigration, 10.

4 Walzer, Spheres of Justice: A Defence of Pluralism and Equality, 31-50.

5 Kukathas, "Why Open Borders?," 670.

6 Pécoud and de Guchteneire, "International Migration, Border Controls and Human Rights: Assessing the Relevance of a Right to Mobility," 81.

7 Pécoud and de Guchteneire, 81.

8 Held, "Law of States, Law of Peoples: Three Models of Sovereignty."

9 Sassen, “Borders, Walls, and Crumbling Sovereignty”; Bauder, “Open Borders: A Utopia?”; Kukathas, "Why Open Borders?”; Pécoud and de Guchteneire, "International Migration, Border Controls and Human Rights: Assessing the Relevance of a Right to Mobility."

10 Miller, National Responsibility and Global Justice, 47.

11 Miller, 48. 
Miller seems to me to be silencing his critics who see him as someone that does not at all appreciate the principle of humanity but rather nationality. Miller is popular for his nationalistic view that our first allegiance and obligation is to our national community and to our fellow-nationals before any commitment to strangers and outsiders. ${ }^{12}$ But the recognition of the humanity of others over nationalistic view seems to portray him in a new light. He did not stop there, he equally suggests that "one could not justify infringing the basic rights of outsiders even where this was necessary to provide the resources to protect the basic rights of compatriots" ${ }^{13}$ In addition to that, he states that he is "doubtful that one would be justified in infringing a stranger's rights in order to avoid infringing a compatriot's".${ }^{14}$ I think Miller sounds more accommodating to the idea of humanity as a moral right to equality which is not predicated on membership status. Therefore, across the spectrum of political ideologies, there seems to be a consensus that immigrants' vulnerability is a problem that must be addressed head-on.

In this paper, I explore how moral and political theorists appeal to the idea of humanity as a panacea to address this problem. But the manner at which they use the concept of humanity is worrisome because it is narrowly conceptualised. The problem I seek to address is that the humanity of immigrants to which we 'owe' respectful treatment is a virtue of acting on moral principles rather than value-bestowing property or common ownership of the earth. To broaden the scope, I shall discuss three different meanings of humanity. First, I discuss 'humanity' as the common ownership of the earth. Second, I discuss 'humanity' as a value property. Third, I discuss humanity as a virtue of acting, on the one hand with humanity, and on the other hand, on moral principles. In the concluding part, I affirm the good will reading of 'humanity' as the most viable account. I affirm that only through the reading of good will can we explain why our moral obligation to help immigrants to pursue their ends must not include their immoral ends.

\section{Humanity as the Common Ownership of the Earth}

Bader, Abizadeh, Held, Beck, and Sznaider have expressed the urgent need to protect immigrants against all forms of inhumane treatment: if not for anything, at least for the sake of humanity. ${ }^{15}$ Also, Benhabib and Cavallar have suggested that immigration policy ought to respect the moral equality of humanity. Cavallar, in particular, alludes that immigrants like every other human being are equal in terms of their humanity and dignity, and their moral vocation. ${ }^{16}$ These scholars defend a commitment to the equal dignity of all individuals and to the fundamental fact of shared humanity.

Mathias Risse took this commitment to another dimension. In his book On Global Justice, Risse asserts that humanity refers to collective ownership of the earth. ${ }^{17} \mathrm{He}$ argues that if the earth belongs to humanity in common, our assessment of immigration policy should be shaped by it. ${ }^{18}$ Risse makes this assertion while trying to rationalise how illegal immigration could be plausibly defended. He finds the problem of illegal immigration very puzzling, so much that he was curious to know how illegal immigrants should be treated. He furthers his curiosity with an additional question concerning whether they are actually doing something wrong. Risse concludes that the idea of "common humanity" is a possible answer to the injustice being done to illegal immigrants. ${ }^{19}$ He defends illegal immigration as a legitimate response to restriction of immigration on the basis that "humanity as a whole owns the earth and its resources in common". ${ }^{20}$

12 Miller, On Nationality.

13 Miller, National Responsibility and Global Justice, 48.

14 Miller, 48.

15 Bader, "The Ethics of Immigration," 354; Bader, Citizenship and Exclusion; Beck and Sznaider, "Unpacking Cosmopolitanism for the Social Sciences: A Research Agenda,” 12; Abizadeh, "Liberal Egalitarian Arguments for Closed Borders: Some Preliminary Critical Reflections,” 3; Held, “Cosmopolitanism: Taming Globalization,” 514.

16 Cavallar, Kant's Embedded Cosmopolitanism: History, Philosophy, and Education for World Citizens, 12.

17 Risse, On Global Justice.

18 Risse, “On the Morality of Immigration," 25.

19 Risse, On Global Justice, 9.

20 Risse, "On the Morality of Immigration," 27. 
Risse’s defense of illegal immigration reads thus:

"True, they are breaking the law, but, arguably, from a moral standpoint, not all ways of breaking the law are to be condemned. If one subscribes to the belief that there should be constraints on the sovereignty of any given state, it is no longer obvious that anything is morally wrong with illegal immigration per se. Specifically, if a country limits immigration in a manner that goes beyond what it is morally entitled to, illegal immigration is a legitimate response. One important way in which sovereignty should be constrained emerges from the idea that humanity as a whole owns the earth and its resources in common". ${ }^{21}$

Risse's argument is predicated on the philosophies of the seventeenth-century philosophers such as Grotius, Locke, Pufendorf, Selden, Filmer and even Kant and Hobbes who suggested that the earth collectively belongs to all of humanity. Furthering this argument, Blake and Risse apply it to immigration. ${ }^{22}$ In their review of the writings of the seventeenth-century philosophers, Blake and Risse singled out Kant for criticism because he limits cosmopolitan right only to rights of visitation without an entitlement to immigration. According to Blake and Risse, Kant offers "no reason for the relatively restricted nature of this right". ${ }^{23}$ Their analysis seems to suggest that Kant does not fully earnest the richness of the original common ownership. This is a substantive issue that I do not have space to address here but I will resort to addressing it in proxy by recommending Alice Walla's article as a rejoinder to Blake and Risse's criticism of Kant. ${ }^{24}$

Some of the recent sympathizers of Blake and Risse's argument include Kieran Oberman, Anna Stilz, and Arash Abizadeh. ${ }^{25}$ Oberman offers a defense argument for Risse in particular. Although, he thinks the 'Common Ownership's argument fails to include people whose interests in the land are not economical, but still think if it is combined with Hillel Steiner's 'Equal Division' (the argument that “no one possess land without compensating the rest of humanity for it") ${ }^{26}$, we can possibly claim that people have a right to freely immigrate across international borders. Stilz, on the other hand, thinks that Risse's common ownership argument is very encouraging for a global justice discussion and that it "may generate educational, labour market, subsistence, and relocation rights in highly industrialised contexts". ${ }^{27}$ She pointed out that the problem of the poorest people in the world is not lack of access to the land, and rightly so, as most of them are peasants and subsistence farmers, but how to relocate to countries where their economic circumstances can improve. So she concludes that, on Risse's account, "there is no international responsibility to guarantee that they can relocate somewhere else". ${ }^{28}$ For this reason, she is unconvinced that such an argument can be of help for the poorest people to immigrate wherever they can improve their economic condition. I think Stilz's criticism of Risse was solely based on his book On Global Justice. I am sure if she had reviewed Risse's other writings such as "Immigration and Original Ownership of the Earth" that Risse co-authors with Michael Blake and "On the Morality of Immigration", her criticism would be met with answers. Although, I agree that Risse's common ownership is unconvincing as a viable model to defend illegal immigration or relatively open borders on the basis of the humanity of immigrants, I do not see the basis of Stilz's criticism if those two works are ignored.

Abizadeh is another sympathiser who has expressed his admiration of Risse's common ownership, specifically for his attempt to limit the power of states. He thinks that Risse could have put up an argument to constrain the power of states with a more convincing expression than 'common ownership'. Abizadeh suggests that instead of using "inflated language of common ownership" ${ }^{29}$, Risse could have appealed to the humanity of each human being as a free and equal being who must not be coerced with political powers.

Besides Risse's sympathisers, Ryan Pevnick has also alleged that "humanity's putative collective ownership of the earth is somewhat irrelevant to the constraints justice imposes on the formulation of immigration policy". ${ }^{30}$ Pevnick

21 Risse, 27.

22 Blake and Risse, "Immigration and Original Ownership of the Earth," 134-38.

23 Blake and Risse, 135.

24 Walla, "Common Possession of the Earth and Cosmopolitan Right."

25 Abizadeh, "A Critique of the "Common Ownership of the Earth' Thesis”; Stilz, "On Collective Ownership of the Earth”; Oberman, "Immigration and Equal Ownership of the Earth"; Walla, "Common Possession of the Earth and Cosmopolitan Right.”

26 Oberman, "Immigration and Equal Ownership of the Earth,” 146.

27 Stilz, “On Collective Ownership of the Earth,” 509.

28 Stilz, 510.

29 Abizadeh, "A Critique of the "Common Ownership of the Earth' Thesis," 39.

30 Pevnick, Cafaro, and Risse, “An Exchange: The Morality of Immigration,” 241. 
argues that Blake and Risse considerably overemphasize the importance of the original common ownership. He criticises them both, but more specifically, Risse for underestimating the difference "between natural resources and political or social resources". ${ }^{31}$ He argues that although we may lay claim to collective ownership of the surface of the earth as the reason to ask for a fairly equal distribution of natural resources, the goods that are of interest to all are characteristically the result of joint political or social enterprises. These include health care, public education, pension schemes, and the economy. In addition, he argues that if immigration restrictions were to be constrained through equal distribution of natural resources, there are still some other moral considerations such as ownership claims by political communities on institutions they have created and whether citizens endorse the immoral obligation to legalise illegal immigration. ${ }^{32}$

I tend to side with Pevnick for two reasons: first, the equal possession of the surface of the earth theoretically applies only to natural rights rather than human rights. Second, the goods and services involved in immigration are beyond the scope of natural rights' claim to humanity. Since Blake and Risse's claim rests on the right that all human beings have merely as human beings and that they do not have to be acquired by an act of choice, then it cannot be referred to as human rights. ${ }^{33}$ Human rights refer to "rights to non-interference and rights to goods and services" ${ }^{34}$, so I do not see how natural rights can be associated with the socioeconomic rights that human rights denote. I, specifically, do not see how it can be the ground of immigrants' rights to immigration.

Miller has also criticised the 'original common ownership' argument by stating that "we cannot in the name of common sense or common humanity throw out the rulebook in favour of a free-for-all”. ${ }^{35}$ Miller is simply saying that we cannot leave the border open because immigrants are prone to vulnerability due to immigration control. He thinks that if we only prioritise hard cases of immigrants, the foundation of immigration policies would be weakened. Miller opines that immigration policy ought to reflect "the overall shape and character of the society" rather than the interest of would-be immigrants. In immigration discussion, we must think less about counterfactual idealisation, and not rely on our intuitions about individual cases of immigrants. ${ }^{36}$ In the context of immigration, injustice can only be adequately addressed, if and only if, each party discharges their own duties. ${ }^{37}$ Here, I think Miller is referring to the negative duty each person has - to refrain from immoral or illegal actions that can infringe upon their own basic rights. That our commitment to moral equality lies in the hands of immigrants and states because they both have a part to play.

I do agree with Miller that there must be a counter-obligation in immigration, and indeed, this is the primary presupposition of this paper. I believe all human beings are equal regardless of their immigration status but have a moral obligation to respect the right of humanity in their own person and in others. I shall next discuss the second sense of humanity in the context of immigration. I explore the idea of humanity as a value-bestowing property in the works of Amartya Sen, Seyla Benhabib, and Chandran Kukathas.

\section{Humanity as a Value Property}

There are different accounts of humanity as a value property. Some use 'humanity' to refer to the human species, while others use it to refer to special value property possessed only by the human species which entitles them to be treated with respect and dignity. Amartya Sen uses humanity to refer to a value property. Sen construes humanity as the ground of human rights and individual entitlement to justice. The idea of 'human rights is constructed on our shared humanity' because these rights are not dependent on being a citizen of any country, or a member of any nation, but on "the entitlements of every human being". ${ }^{38}$ Sen says that a better understanding of the value of human beings greatly matters in our conception of humanity. That we should not be deluded to equate the needs of people with their value. As he puts it, "Certainly, people do have needs, but they also have values and, in particular, cherish their ability to

31 Pevnick, Cafaro, and Risse, 241.

32 Pevnick, Cafaro, and Risse, 241-42.

33 Gregor, “Natural Right or Natural Law?,” 11.

34 Gregor, 11.

35 Miller, Strangers in Our Midst: The Political Philosophy of Immigration, 159.

36 Miller, 159.

37 Miller, 193.

38 Sen, The Idea of Justice, 143. 
reason, appraise, choose, participate and act. Seeing people only in terms of their needs may give us a rather meagre view of humanity". ${ }^{39}$ On Sen's account, humanity grounds the principle of justice whereby individuals' entitlement is the basis of the ideal configuration or distribution of rights and resources. Although, Sen uses humanity closely related to economic rights or resources every human being is entitled, rather than immigrants per se.

Seyla Benhabib, like Sen, seems to assert that there is individuals' entitlement to human rights on the basis of humanity. Benhabib claims that 'hospitality is a right' insofar as humanity belongs to all human beings who are equal members of a world republic. ${ }^{40}$ She locates the right of hospitality within "the boundaries of the polity; which delimits civic space by regulating relations among members and strangers". ${ }^{41}$ This implies that the right of hospitality is situated between "human rights and civil rights, between the right of humanity in our person and the rights that accrue to us insofar as we are members of specific republics". ${ }^{42}$ Here, Benhabib also appears to express a similar argument, like Blake and Risse, that on the basis of common ownership of the earth, every human being may legitimately make claim to a right to immigrate freely, but this does not imply an open border argument. Her argument reads that in virtue of our common humanity immigrants have rights that are not dependent on their citizenship within states. ${ }^{43}$

As a moral being, Benhabib argues that our "freedom can only be constrained through reasons that satisfy the conditions of formality, generality, and reciprocity for all”. ${ }^{44} \mathrm{By}$ this, she means the right we have to have rights entails that there is the acknowledgment of our identity as human beings with entitlement as well as the equal common owner of the surface of the earth who has needs. Her claim is that in virtue of our common humanity, we are equal and have the right of reciprocity over one another. As she puts it,

\footnotetext{
"If I recognize you as a being entitled to rights only because you are like me, then I deny your fundamental individuality which makes you different. If I refuse to recognize you as a being entitled to rights because you are so other than me, then I deny our common humanity. The standpoint of the "generalized other" requires us to view each and every individual as a being entitled to the same rights and duties we would want to ascribe to ourselves. In assuming this standpoint, we abstract from the individuality and the concrete identity of the other. We assume that the other, like ourselves, is a being who has concrete needs, desires, and affects, but what constitutes his or her moral dignity is not what differentiates us from each other, but rather what we, as speaking and acting and embodied beings, have in common. Our relation to the other is governed by the norms of formal equality and reciprocity: each is entitled to expect from us what we can expect from him or from her. In treating you in accordance with these norms, I confirm in your person the rights of humanity and I have a legitimate claim that you will do the same in relation to me". ${ }^{45}$
}

In the just quoted texts, Benhabib tries to explain that the relationship we have with one another is ruled by the ethical norms of equity and matching reciprocity. No matter the differences we may have as humans, the fact that we are equal and have reciprocal rights ought to 'complement rather than exclude us from one another'. For instance, in treating an immigrant as my moral equal, I approve not only of his humanity but also of his human individuality. For this reason, Benhabib says if all human beings deserve respect by virtue of their humanity, immigrants as appear to have legitimate expectations to experience altruism and solidarity from the generalised others. ${ }^{46}$ In closing her argument, Benhabib said if this is true, then "it is an insult to the dignity and freedom of individuals everywhere" to assume that not all human beings are entitled to rights in virtue of their humanity alone. ${ }^{47}$

My objection to her account is closely related to what I had earlier noted about Blake and Risse's common ownership. But I think there are two additional issues with Benhabib's. First, her conception of freedom and rights, like Sen, seem to rest on the supposition of natural rights which many right-based liberals appear to consider a non-issue. Natural rights and human rights are not synonymous, as I earlier pointed out. Second, Benhabib seems to be saying that since the surface of the earth belongs to humanity in common, the restriction of immigration cannot be justifiably legitimate

39 Sen, 250.

40 Benhabib, The Rights of Others: Aliens, Residents, and Citizens, 26.

41 Benhabib, 27.

42 Benhabib, 27.

43 Benhabib, Dignity in Adversity: Human Rights in Turbulent Times, 13.

44 Benhabib, 69.

45 Benhabib, 69.

46 Benhabib, 69.

47 Benhabib, 114 
- and advocates instead for porous boundaries. But does it matter, for Benhabib, if the means to achieve a cosmopolitan right of foreigners is achieved through injustice or immorality?

Furthermore, Benhabib has indicated that her understanding of cosmopolitanism is situated in Kant's tradition, ${ }^{48}$ but there are at least three differences between her reading of cosmopolitanism and Kant's. First, unlike hers, Kant does not ground his principles of cosmopolitanism on claims about individuals' entitlements to wild freedom, rather on constrained freedom. ${ }^{49}$ Kant's idea of a universal cosmopolitan condition must first be reflected as an argument for freedom under external lawful constraint. Both in the Teleological Judgement of the Critique of the Power of Judgement and the Idea for a Universal History with a Cosmopolitan Aim, Kant insists the "greatest necessity of all" is the formal condition under which human freedom can coexist through lawful power of "civil society" or "universal cosmopolitan condition", a requirement for nature to attain its highest aim..$^{50}$ Kant was concerned about how 'lawless freedom', (a state of affairs whereby a 'thoroughgoing antagonism' in society resulting from 'dissatisfaction from within', 'violence imposed from outside' and a 'state of oppression'), can be restricted.$^{51}$ If not restricted, the reciprocally conflicting freedom between human beings would inevitably lead the human species to anarchy. ${ }^{52}$ Second, contrary to Benhabib's claim, Kant does ground his theory of cosmopolitanism on natural law, ${ }^{53}$ but on a universal cosmopolitan condition whereby "lawfulness together with the freedom of the states" can be achieved..$^{54}$ Third, Benhabib advocates for porous boundaries but Kant advocates for territorial justice where there is secured enforcement of standards of justice. In my view, Kant's cosmopolitan claim is a realistic account of justice that sets the standard for enforceability of the law, thus the burden of proof as to how Kant can solve the problem of enforcement and coercion (as often alleged) ${ }^{55}$ is not on him, but his critics, to provide alternative accounts of justice that can protect individual entitlement to freedom of movement without committing us to injustice and immorality. The alternative account must necessarily pass the test of "feasibility and permissibility of enforcement." ${ }^{56}$

Chandran Kukathas, unlike Benhabib or Sen, took a bold step to argue for an open border. He indicated that an open border argument may prevail if it appeals to the principle of freedom and the principle of humanity. First, he argues that since closed borders restrict freedom of movement, it is inconsistent with the protection of human freedom. Kukathas says if freedom is held to be a value of special magnitude, it deserves our preservation, promotion, and protection. He explains that "To keep borders closed would mean to keep out people who would, as a consequence, lose not only the freedom to move but also the freedom they might be seeking in an attempt to flee unjust or tyrannical regimes". ${ }^{57}$ The hard case of refugees and humanitarian immigrants was especially expressed as the reason to appeal to the principle of freedom.I think one must be heartless to deny that this category of immigrants does not deserve special intervention. Indeed, they require the utmost level of humanitarian action and protection. At the same time, I think an immigration policy should holistically address the issues of all immigrants (without preferential treatment for hard immigration cases alone) with the same sense of urgency.

We must not overemphasise hard immigration cases. If, going by immigration statistics, the hard cases represent only 1 out of 10 of international immigrants: "despite the recent sharp increase in international immigration numbers,

48 Benhabib, “Reclaiming Universalism: Negotiating Republican Self-Determination and Cosmopolitan Norms,” 119.

49 O’Neill, “Cosmopolitanism Then and Now,” 357.

50 Kant, Critique of the Power of Judgment, 299; Kant and Wood, “Idea for a Universal History with a Cosmopolitan Aim,” 112.

51 Kant, Critique of the Power of Judgment, 299-300; Kant and Wood, “Idea for a Universal History with a Cosmopolitan Aim,” 112; Kant, Lectures on Natural Law Feyerabend, 20; Kant, Anthropology, History, and Education, 446-47; Kant, The Metaphysics of Morals, 124.

52 For Kant, anarchy negates the very idea of a republic where a true civic constitution can be established, and as long as it is established the rational being must preserve the constitution because a civil society can only endure under a civic constitution. See, Kant, Anthropology, History, and Education, 425.

53 Benhabib, "Reclaiming Universalism: Negotiating Republican Self-Determination and Cosmopolitan Norms,” 125.

54 Kant, Critique of the Power of Judgment, 300.

55 Pauline Kleingeld, “Kant's Cosmopolitan Law: World Citizenship for a Global Order,” Kantian Review 2 (1998): 81-83; Robert Fine, “Kant’s Theory of Cosmopolitanism and Hegel's Critique,” Philosophy \& Social Criticism 29, no. 6 (November 1, 2003): 463; Robert Fine, “Cosmopolitanism and Humanitarian Military Intervention: War, Peace and Human Rights This,” in Cosmopolitanism, 2007, 86,88; Pauline Kleingeld, "Kant's Changing Cosmopolitanism," in Kant's Idea for a Universal History with a Cosmopolitan Aim: A Critical Guide, ed. Amélie Rorty and James Schmidt (Cambridge University Press, 2009), 179-86; Georg Cavallar, Kant’s Embedded Cosmopolitanism: History, Philosophy, and Education for World Citizens (De Gruyter, 2015), 12.

56 O’Neill, “Cosmopolitanism Then and Now,” 364.

57 Kukathas, “The Case for Open Immigration,” 210. 
refugees and asylum seekers represent a small share of all immigrants" ${ }^{58}$ Given this figure, it would also be unfair and insulting to the dignity of 90 percent of the other immigrants if their immigration issues are to be shaped by the hard cases of only 10 percent. If this does not come across to liberals and cosmopolitans as unjust, I doubt if their commitments to moral equality are truly grounded in democratic principles.

The dimension Kukathas brought to the idea of human freedom is interesting, as he appears to describe freedom in terms of an economic model, whereby someone can instrumentalise his freedom. According to him, "closing borders means denying people the freedom to sell their labour, and denying others the freedom to buy it". ${ }^{59}$ There must be a good justification to deny people their freedom to economic prosperity because "to deny someone the liberty to exchange his labour is to deny him a very significant liberty".${ }^{60} \mathrm{He}$ opposed the idea of restricting people's freedom of right to associate, instead of freedom of movement because it keeps apart people from their loved ones such as caring for children or parents, or friends, or from satisfying important obligations.$^{61} \mathrm{I}$ am wary if this economic model is not just a way to instrumentalise our freedom as a commodity that is up for rational trade-off. It sounds paradoxical to me to make such a claim and at the same time to claim that we have a dignity that is incomparable and above all price.

Second, Kukathas appeals to the principle of humanity to lend support for open borders. His appeal to humanity principle is motivated by the belief that the poorest people in the world ought to have the most promising way of improving their condition, and the surest way, according to Kukathas, is for them to have a way to move to more prosperous countries. ${ }^{62}$ (Perhaps, Kukathas' account will satisfy Stilz's criticism of Risse, as earlier discussed). Kukathas furthers that:

\footnotetext{
"A principle of humanity suggests that very good reasons must be offered to justify turning the disadvantaged away. It would be bad enough to meet such people with indifference and to deny them positive assistance. It would be even worse to deny them the opportunity to help themselves. To go to the length of denying one's fellow citizens the right to help those who are badly off, whether by employing them or by simply taking them in, seems even more difficult to justify - if, indeed, it is not entirely perverse. Not all people who look to move are poor or disadvantaged. Nor do all of them care about freedom. But if freedom and humanity are important and weighty values, the prima facie case for open borders is a strong one, since very substantial considerations will have to be adduced to warrant ignoring or repudiating them". ${ }^{63}$
}

In his concluding remarks, Kukathas suggests that 'the standard of open borders should prevail' if immigrants' condition is defended from "the perspective of a principle of freedom, or a principle of humanity". ${ }^{64}$

While I understand Kukathas' description of freedom in terms of an economic model, I do not really grasp his description of the principle of humanity per se. It is unclear to me whether he thinks humanity is an argument for benevolence to alleviate the suffering of the poorest people in the world, or an appeal to the inner value of every rational being for having the capacity to make choices for themselves, or an appeal to the common ownership of the surface of the earth.

To finalise this section, Sen, Benhabib, and Kukathas seem indifferent about immoral and illegal acts in the context of immigration such as marriage fraud, visa overstay, human shield (children and women). I do not find them grappling with how to rationalise ways to deal with these loopholes in immigration. Perhaps, Kukathas would say those are a legitimate response to harsh immigration laws. One begins to wonder if there are limitations to offences immigrants can commit that Sen, Benhabib, and Kukathas would deem inappropriate. At the moment, their approach to immigration loopholes seems to suggest that anything goes, as they often appeal to individual entitlement and autonomy to shield immigrants from facing justice or punishment for the immorality and illegality they have committed. But does immigration law constitute a constraint on immigrant's autonomy? As Mary Gregor and Gunnar Beck noted:

58 Barbara Kobler, and Pablo Lattes. "International Migration Report 2017: Highlights (ST/ESA/SER.A/404)", 3.

59 Kukathas, “The Case for Open Immigration,” 210.

60 Kukathas, 210.

61 Kukathas, 210

62 Kukathas, 211.

63 Kukathas, 211.

64 Kukathas, 214. 
"Constraint to this end is just and does not constitute a violation of individual autonomy because the bounds set by the rule of law are necessary to enforce those conditions of mutual external freedom subject to which alone a multiplicity of co-existing individuals may choose for themselves which ends to pursue free from restraint by others". ${ }^{65}$

Immigration laws are not designed to be a hindering hinderance on immigrants' autonomy, they are designed to protect the rights of every party involved including immigrants. This is why immigrants cannot be relied upon to observe the law voluntarily, it must be enforced by the immigration officials. Observance of their duty to respect the law is the condition under which each immigrant can enjoy freedom necessary for autonomy. Having to make critical notes on all accounts of humanity thus far, either as common ownership of the earth or as a value property, I consider next 'humanity' as a virtue.

\section{Humanity as a Virtue}

Sangiovanni, in his book Humanity without Dignity, rejects theoretical approaches that ground our commitment to moral equality on the conception of humanity as a value property. Sangiovanni offers a radical account of humanity that rejects the dominant position in contemporary moral and political theory, that we are entitled to equal respect merely as persons. To the contrary, our commitment to moral equality must begin with a reflection of inequality, rather than of equality. ${ }^{66}$ In a similar spirit to P. F. Strawson, Sangiovanni approaches the problem of moral responsibility in a reactive attitude. Sangiovanni develops what he describes as the "Negative Conception" of the moral equality of each human being. Instead of committing ourselves to a positive conception of moral equality or looking for a phantom value-conferring capacity we all possess as human beings, Sangiovanni says we should have a negative commitment to moral equality by asking: why and when is it morally wrong to treat persons as inferior? His answer to this question is that the idea of humanity is founded in a fundamental moral right of each human being not to be treated as inferior.

Sangiovanni discusses different ways of treating people as inferior that are socially cruel, which include dehumanising, objectivating, infantilising, instrumentalising, and stigmatising treatment. ${ }^{67}$ What Sangiovanni considers as forms of wrongdoing that are all socially cruel to human beings is best captured in his description of social cruelty. Sangiovanni describes social cruelty as "the unauthorized, harmful, and wrongful use of another's vulnerability to attack or obliterate their capacity to develop and maintain an integral sense of self" ${ }^{68}$ In immigration discussion, Sangiovanni is inclined to say inasmuch as immigrants' ability is constrained not to have "an integral sense of self" (through trafficking, deportation, abuse), they are treated as inferior, and such treatment must be rejected.

At the heart of Sangiovanni's argument against social cruelty is the claim that "humanity is a disposition to show empathy' for others. Humanity as a disposition is predicated on the idea of "sociability" propensity of human beings that flows from "the capacity for friendship, love, conviviality, and morality" ${ }^{69}$ So, "humanity, for Sangiovanni, is best described as "the disposition to projectively imagine the world from another's point of view, to seek an 'accord and symphony', and to accept reason as a ground for reflecting on what to do and what we owe to others." ${ }^{\text {"0 }}$ It implies that to act with humanity is to care for those "who need to be cared for while reinforcing their sense of self". ${ }^{71}$

Sangiovanni, however, points out that to respect another as an equal, that other needs to be treated with "opacity." By this, he means that "knowing when to pierce the veil of opacity will require acting with humanity". ${ }^{72}$ That is, we cannot just disregard the self-presentation of vulnerable people (like immigrants), as if what concerns them does not matter, doing so is cruelty. His point is that we cannot overlook or downplay the wrongness of the social-relational aspect of discriminatory practices. Rather than assuming that "the arbitrary physical violence, denial of liberty, or economic deprivation" are the most wrongful discriminatory practices, we should instead recognise that by denying

65 Beck, “Immanuel Kant’s Theory of Rights,” 375. See also, Gregor, Laws of Freedom, 28.

66 Sangiovanni, Humanity Without Dignity: Moral Equality, Respect, and Human Rights, 103.

67 Sangiovanni, 74.

68 Sangiovanni, 76.

69 Sangiovanni, 69.

70 Sangiovanni, 69.

71 Sangiovanni, 91.

72 Sangiovanni, 108. 
vulnerable people of social recognition and opacity of respect, we are giving them inferiorising treatment. ${ }^{73}$ Without the social-relational aspect to it, the character and wrongness of these discriminatory practices cannot be understood. For this reason, Sangiovanni advocates for the opacity of respect. Sangiovanni claims opacity respect can "protects us against social cruelty, against attempts to break or otherwise obliterate our capacity to develop and maintain an integral sense of self and thereby makes it possible for us to enjoy the most important goods" ${ }^{74}$ So, by his account, "our commitment to moral equality is both grounded in and constituted by our rejection of inequality". ${ }^{75}$ Our rejection of inequality presupposes that 'inequality is prior to equality'. Sangiovanni then offers two reasons why 'inequality is prior to equality': first, our commitment to moral equality is grounded in a fundamental moral right not to be treated as inferior, and, second, moral equality is "grounded in the rejection of inferiorising treatment as socially cruel". ${ }^{76}$

It must be noted that Sangiovanni's account seems to follow the egalitarian tradition. One pointer to this is that he consistently connects opacity respect, social cruelty and moral equality with certain forms of social relations. For instance, suppose an immigrant is wrongfully discriminated against by either lack of access public services or for racial profiling, such action is unquestionably wrong, and violates our moral equality, but how? Sangiovanni tends to answer that the violation occurs not because the victim was deprived of social opportunities but because it has "social meaning" that produces "objectionable relational nexuses". ${ }^{77}$ He suggests that by looking at the message a policy or an act sends, we can determine whether the social meaning contained therein is discriminatory. As he explains it, we can make the determination by considering "the attitudes that it expresses against a wider social, cultural, political, economic background". ${ }^{78}$ The overall aim of Sangiovanni's account is to show that wrongful discrimination is socially cruel because it demeans or degrades victims' sense of self.

I find Sangiovanni's account very timely to challenge the dominant view of dignity and humanity as a valuebestowing property and emphasis instead that humanity is a virtue of acting morally to reinforce our sense of self. I agree with Sangiovanni that we cannot understand better our commitment to moral equality by grounding our theoretical explanation and justification in the "Aristotelian" claim about our elevated position or rank, or the "Christian/ Thomistic" claim that connects us to a transcendental or spiritual realm, or the "Kantian" claim that relies on our capacity for rationality and autonomy. Sangiovanni, indeed, sets the ball rolling for a debate about how we should approach the question of the treatment of persons. Yet, I do not really think that Sangiovanni's account has done much-needed justice to how an immigrant's vulnerability can be addressed both in action and policy, in a way that creates an obligation to every party involved. While he moved the goalposts from dignity-conferring property to treating each human being as not inferior in moral status to oneself, I am not sure whether, on Sangiovanni's account, we can assign a counterpart obligation to immigrants to always act out of a good will toward others and the rule of law.

Since Sangiovanni thinks, like Strawson, that judgments about moral responsibility must be understood in a reactive attitude ${ }^{79} \mathrm{I}$ think he would contend that it is needless to have the desire for good will because moral responsibility does not need to depend on an external justification. Although Sangiovanni is correct that objectification and cruelty are more central to the idea of vulnerability that immigrants faced, this needs to be balanced with the moral obligation of immigrants to prioritise morality over immorality and illegalities. I think immigrants do have a responsibility to act with moral decency even if it does not make up for their preferred plans.

Some of the ways to reduce the intensity of exclusionary sentiment in immigration discourse include blocking the loopholes in the immigration process that immigrants are exploiting to violates the rule of law as well as moral duties to themselves and others. The loopholes include such issues as child trafficking or unaccompanied children immigrants, sham marriage, visa overstay, fake refugee and asylum seekers. These loopholes are grey areas that moral and political thinkers must address very urgently. In recent years, the argument against cosmopolitanism is loud and clear that unless these loopholes are blocked, our commitment to defend immigrants' rights on the basis of humanity would be met with hostility. I think those loopholes cannot just be brushed aside, they deserve our attention and require a

73 Sangiovanni, 136

74 Sangiovanni, 95.

75 Sangiovanni, 103.

76 Sangiovanni, 103.

77 Sangiovanni, 121-22.

78 Sangiovanni, $122-23$.

79 Strawson, "Freedom and Resentment”; Sangiovanni, Humanity Without Dignity: Moral Equality, Respect, and Human Rights. 
broader moral approach that will allocate moral obligation equally to every party involved, and concurrently, assure the treatment of immigrants with dignity and respect.

In the light of this, I suggest that we need to turn to the traditional reading of Kantian ethics which identified exclusively with the principle of universalizability as the moral approach that can guarantee moral equality for every party involve. By turning to Kant's ethics, we must approach the idea of humanity differently from what Sangiovanni criticises and describes as the "Regress Reading" of Kant (Christine Korsgaard's Enlightenment morality) and the "Address Reading" (Stephen Darwall and Rainer Forst's commitment to the equal moral authority). ${ }^{80}$ I agree with Sangiovanni that both readings are not the best moral approaches, but I disagree with him on the premises with which he rejects Kantian account of dignity. I think he ignores other Kantian readings and focuses strictly only on those two readings. He, for instance, did not allude to the fact that the traditional reading of Kant has a contrary account of humanity and dignity. As I see it, both "Regress Reading" and "Address Reading" are best described as the emerging (new) interpretation of Kant's ethics (arguably the dominant one right now), trying to replace the traditional reading.

I embrace the traditional reading to emphasise that humanity is really the good will. My reading of humanity is patterned after models of Richard Dean's good will reading, which commits us to act on the moral principles demanded by our own power of reason. According to this model, "humanity is only possessed by a being who actually accepts moral principles as providing sufficient reasons for action. The humanity we 'owe' respectful treatment is a properly ordered will, which gives priority to moral considerations over self-interest", ${ }^{81}$ and that is a good will. One good feature of this model is that it provides us with reasons never to act immorally. Unlike the other accounts I have explored in this paper, this model provides us with a realistic moral principle that is action-guiding on practical issues. For instance, it can easily answer the question that cosmopolitans often dodge: does it really matter if the means by which an immigrant immigrates is demeaning or degrading to his own humanity as a person, or is achieved through injustice or immorality? This question seems trivial for cosmopolitans who appear not to be concerned about the immorality or illegality immigrants are committing but those committed against them. On this model, we can explain why our moral obligation to help immigrants to pursue their ends must not include their immoral ends.

This model recognises that the traditional reading of Kant is unpopular because the exponents of what Sangiovanni describes as "Regress Reading" and "Address Reading" are "steeped in liberalism's emphasis on the foundational importance of choice".$^{82}$ For this reason, they appear to think that by construing humanity as the good will, it would have "unpalatable moralistic consequences" on their political and ethical agenda. It will reinforce "the demand to judge others' moral character", and to make "differential treatment based on those judgments". ${ }^{33}$ This model, however, disputes that it is a misguided assumption because the moralistic demand Kant asks of us is simply to prioritise moral considerations over our self-interest and nothing more. Our commitment to moral equality cannot rely on claims about the value of humanity as value-bestowing property; one that we can do no wrong. It suggests instead that such claims can only describe our prior ideas about humanity - that in virtue of the capacities that makes us superior to other creatures in nature, we all deserve treatment with respect and dignity. Beyond this point, humanity is actually a fundamental principle of morality. That it is only when we treat humanity as a virtue of acting on moral principles that it can be applied to particular moral issues such as the treatment of immigrants.

\section{Conclusion}

Evidently, I have not covered the entire range of philosophical and political aspects of the question of the treatment of immigrants. I have tried to show some of the more important aspects of the discussion (such as the conceptual issue of the idea of humanity) and discuss what might be considered challenges to the theoretical issues. To sum up, the discussion has apparently successfully appealed to the idea of humanity as a panacea to the problem of immigrants' vulnerability. However, this discussion leaves us facing a problem of the conceptual meaning of humanity, of how to justify the need for the promotion and protection of respectful treatment of immigrants on the basis of humanity.

80 Sangiovanni, Humanity Without Dignity: Moral Equality, Respect, and Human Rights, 37-71.

81 Dean, The Value of Humanity in Kant's Moral Theory, 6.

82 Dean, "The Formula of Humanity as an End in Itself," 86.

83 Dean, 87. 
The most common conceptual meaning of 'humanity' is value-bestowing property, either as common ownership of the earth or as equal dignity of all persons. So regardless of immigrants' actions, they are owed respectful treatment. This theoretical approach is somewhat less successful because it fails to be action-guiding and a viable ground for our commitment to moral equality. For instance, there is no moral incentive for an immigrant to choose to act morally since if he acts immorally, he would not be losing something of incomparable value. Alternatively, Sangiovanni offers a radical account of humanity which proposes that our commitment to moral equality must begin with a reflection of inequality, rather than of equality. While we should be thankful to Sangiovanni for alerting us to the disadvantage of the conception of humanity as a dignity-conferring property, by emphasising instead that humanity is a commitment to the treatment of each human being not as inferior in moral status to oneself, Sangiovanni fails to provide us a reason to or not to assign a counterpart obligation to immigrants to always act out of a good will toward others and the rule of law as much as they want to be treated. I have thus tried to raise issues and make suggestions which can help us address grey issues as identified.

The analysis here does not, of course, resolve these issues. It is, however, meant to keep the reader abreast with the issues and offer them an insight into an alternative account. For this reason, I propose that, in the field of immigration studies, 'humanity' should be conceived as a virtue of actual commitment to act on moral principles. That immigrants must endeavour to reach a moral ideal of acting rightly and giving priority to moral consideration over self-interest. I suggest that the principle of humanity does not prescribe only the form of treatment immigrants must receive but also how they allow themselves to be treated; humanity forbids not only that they should not be mistreated but also that they do not violate a self-regarding duty, that they do not dispose themselves to the shame of humanity and act contrary to the right thereof. Therefore, immigrants are just as much commanded not to suffer injustice as not to commit injustice.

\section{References}

Abizadeh, Arash. “A Critique of the 'Common Ownership of the Earth’ Thesis.” Les Ateliers de l'éthique/The Ethics Forum 8, no. 2 (2013): 33-40.

---. "Liberal Egalitarian Arguments for Closed Borders: Some Preliminary Critical Reflections." Éthique et Économique/Ethics and Economics 4, no. 1 (2006): 1-8.

Bader, Veit. Citizenship and Exclusion. London: Macmillan Press, 1997.

---. "The Ethics of Immigration." Constellations 12, no. 3 (2005): 331-61.

Bauder, Harald. “Open Borders: A Utopia?” Journal of Spacial Justice 5 (2012): 1-13.

Beck, Gunnar. “Immanuel Kant’s Theory of Rights.” Ratio Juris 19, no. 4 (2006): 371-401.

Beck, Ulrich, and Natan Sznaider. "Unpacking Cosmopolitanism for the Social Sciences: A Research Agenda." British Journal of Sociology 57, no. 1 (2006): 1-23.

Benhabib, Seyla. Dignity in Adversity: Human Rights in Turbulent Times. Cambridge: Polity Press, 2011.

-- . "Reclaiming Universalism: Negotiating Republican Self-Determination and Cosmopolitan Norms." The Tanner Lectures on Human Values, 2004.

---. The Rights of Others: Aliens, Residents, and Citizens. Cambridge: Cambridge University Press, 2004.

Blake, Michael, and Mathias Risse. “Immigration and Original Ownership of the Earth.” Notre Dame Journal of Law, Ethics \& Public Policy 23, no. 1 (2009): 133-65.

Bustamante, Jorge A. “Immigrants' Vulnerability as Subjects of Human Rights.” The International Migration Review 36, no. 2 (2002): $333-54$. Cavallar, Georg. Kant's Embedded Cosmopolitanism: History, Philosophy, and Education for World Citizens. Berlin: De Gruyter, 2015.

Cole, Phillip. Philosophies of Exclusion: Liberal Political Theory and Immigration. Edinburgh: Edinburgh University Press, 2000.

Dean, Richard. "The Formula of Humanity as an End in Itself.” In Blackwell Guide to Kant's Ethics, edited by Thomas E. Jr. Hill, 83-101. Oxford: Blackwell Publishing, 2009.

---. The Value of Humanity in Kant's Moral Theory. Oxford: Oxford University Press, 2006.

Fine, Robert. “Cosmopolitanism and Humanitarian Military Intervention: War, Peace and Human Rights This.” In Cosmopolitanism, 78-149, 2007.

---. “Kant's Theory of Cosmopolitanism and Hegel's Critique.” Philosophy \& Social Criticism 29, no. 6 (November 1, 2003): 609-30.

Gregor, Mary. Laws of Freedom. New York: Barnes and Noble, Inc., 1963.

---. "Natural Right or Natural Law?” Jahrbuch Für Recht Und Ethik/Annual Review of Law and Ethics 3 (1995): 11-35.

Held, David. “Cosmopolitanism: Taming Globalization.” The Global Transformations Reader: An Introduction to the Globalization Debate, no. January 2003 (2003): 514-29.

--_. “Law of States, Law of Peoples: Three Models of Sovereignty.” Legal Theory 8, no. 2 (2002): 1-44. 
Kant, Immanuel. Anthropology, History, and Education. Edited by Günter Zöller and Robert B. Louden. Translated by Mary Gregor, Paul Guyer, Günter Zöller, Robert B. Louden, Arnulf Zweig, Holly Wilson, and Allen W. Wood. Cambridge: Cambridge University Press, 2007.

--- Critique of the Power of Judgment. Edited by Paul Guyer. Translated by Paul Guyer and Eric Matthews. Cambridge: Cambridge University Press, 2000.

---. Lectures on Natural Law Feyerabend. Translated by Lars Vinx. Unpublished, 2003.

--- The Metaphysics of Morals. Translated by Mary Gregor. Cambridge: Cambridge University Press, 1991.

Kant, Immanuel, and Allen W. Wood. "Idea for a Universal History with a Cosmopolitan Aim.” In Kant's Idea for a Universal History with a Cosmopolitan Aim: A Critical Guide, edited by Amélie Oksenberg Rorty and James Schmidt, 9-23. Cambridge University Press, 2009.

Kleingeld, Pauline. “Kant's Changing Cosmopolitanism.” In Kant's Idea for a Universal History with a Cosmopolitan Aim: A Critical Guide, edited by Amélie Rorty and James Schmidt, 171-86. Cambridge University Press, 2009.

---. “Kant's Cosmopolitan Law: World Citizenship for a Global Order.” Kantian Review 2 (1998): 72-90.

Kukathas, Chandran. "The Case for Open Immigration." In Contemporary Debates in Applied Ethics, edited by Andrew I. Cohen and Christopher Heath Wellman, 207-20. Oxford: Blackwell Publishing, 2005.

--_. "Why Open Borders?” Ethical Perspectives 19, no. 4 (2012): 649-75.

Miller, David. National Responsibility and Global Justice. Oxford: Oxford University Press, 2007.

---. On Nationality. Oxford: Oxford University Press, 1995.

---. Strangers in Our Midst: The Political Philosophy of Immigration. Cambridge, MA: Harvard University Press, 2016.

O’Neill, Onora. “Cosmopolitanism Then and Now.” In Kant Und Die Philosophie in Weltbürgerlicher Absicht: Akten Des Xi. Kant-Kongresses 2010, edited by Margit Bacin, Stefano; Ferrarin, Alfredo; La Rocca, Claudio; Ruffing, 357-67. De Gruyter, 2013.

Oberman, Kieran. "Immigration and Equal Ownership of the Earth." Ratio Juris 30, no. 2 (2016): 144-57.

Pécoud, Antoine, and Paul de Guchteneire. "International Migration, Border Controls and Human Rights: Assessing the Relevance of a Right to Mobility." Journal of Borderlands Studies 21, no. 1 (2006): 69-86.

Pevnick, Ryan, Philip Cafaro, and Mathias Risse. “An Exchange: The Morality of Immigration.” Ethics and International Affairs 22, no. 3 (2008): 241-59.

Risse, Mathias. On Global Justice. Princeton: Princeton University Press, 2012.

---. "On the Morality of Immigration." Ethics and International Affairs 22, no. 1 (2008): 25-33.

Sangiovanni, Andrea. Humanity Without Dignity: Moral Equality, Respect, and Human Rights. Cambridge, MA: Harvard University Press, 2017.

Sassen, Saskia. “Borders, Walls, and Crumbling Sovereignty.” Political Theory 40, no. 1 (2012): 116-22.

Sen, Amartya. The Idea of Justice. Cambridge, MA: Harvard University Press, 2009.

Stilz, Anna. "On Collective Ownership of the Earth." Ethics \& International Affairs 28, no. 4 (2014): 501-10.

Strawson, Peter F. "Freedom and Resentment." In Proceedings of the British Academy, edited by Gary Watson, 48:1-25. 0xford: Oxford University Press, 1962.

Walla, Alice Pinheiro. “Common Possession of the Earth and Cosmopolitan Right." Kant-Studien 107, no. 1 (2016): 160-78.

Walzer, Michael. Spheres of Justice: A Defence of Pluralism and Equality. New York: Basic Books, 1983. 